Egle Elena Šataite

Generolo Jono Žemaičio Lietuvos karo akademija

\title{
Taikos atstatymo operacijos: Bosnijos ir Hercegovinos atvejis
}

\begin{abstract}
Taikos atstatymo operacijos, kaip viena iš taikos operacijų apskritai sudedamuju daliu, pastaruoju metu tampa vis labiau analizuojamu reiškiniu politikos moksluose, o tokių operacijų tikslai ir uždaviniai vis dažniau atsiduria tarptautinių ir nevyriausybiniu organizacijų darbotvarkejje ir veikloje. Šiandien taikos atstatymo operacijos tapo neatsiejama Jungtinių Tautu (JT) bei Europos Sajungos (ES) vykdomų misijų dalimi. Šios tendencijos taip pat neaplenkia ir NATO, o didžiausia regioninė organizacija - Europos saugumo ir bendradarbiavimo organizacija (ESBO) - veikia išankstinio perspëjimo, konfliktu prevencijos, krizių valdymo, regionų atstatymo po konfliktų srityse.

Šio straipsnio tikslas - išanalizuoti taikos atstatymo operaciju koncepciją ir naudojamas priemones, mechanizmus taikos operacijose. Pirmojoje straipsnio dalyje analizuojama kaip terminas "taikos atstatymo operacijos" naudojamas Jungtiniu Tautu, Europos Sajungos, ESBO ir NATO veikloje. Šios dalies tikslas yra parodyti šiu tarptautinių organizacijų naudojamą terminologiją analizuojamai koncepcijai išreikšti ir koks yra šio termino turinys. Antrojoje darbo dalyje analizuojamos taikos atstatymo operacijos Bosnijoje ir Hercegovinoje didžiausią dėmesį skiriant taikos atstatymo mechanizmams, kuriuos naudojo NATO ir dar tebenaudoja JT, ESBO ir ES. Bosnijos ir Hercegovinos atvejis pasirinktas dẻl aktualumo ES ir Europos saugumui bendrai ir dèl ypatingos šios šalies politinės sistemos, sukurtos Deitono taikos sutartimi.
\end{abstract}

\section{!vadas}

Pastaruoju metu taikos atstatymo operacijos tampa vis labiau analizuojamu reiškiniu politikos moksluose, o tokių operaciju tikslai ir uždaviniai vis dažniau atsiduria tarptautinių ir nevyriausybinių organizacijų darbotvarkëje ir veikloje. Šiandien taikos atstatymo operacijos tapo neatsiejama Jungtinių Tautu vykdomų prevencinės diplomatijos, taikdarystės ir taikos palaikymo operaciju dalimi. Europos Sajunga savo ruožtu aktyviai plètodama civilinius pajėgumus ir vykdydama civilines misijas taip pat igyvendina akademinèje literatūroje taikos atstatymo operacijoms priskiriamas funkcijas. Reikia pripažinti, kad šios tendencijos neaplenkia ir NATO. Didžiausia regioninė organizacija - Europos saugumo ir bendradarbiavimo organizacija - veikia ankstyvo perspëjimo, konfliktų prevencijos, krizių valdymo, regionų atstatymo po konfliktų srityse.

\footnotetext{
* Egle Elena Šataité - Generolo Jono Žemaičio Lietuvos karo akademijos Politikos mokslu katedros lektorè. Adresas: Šilo g. 5A, 10322 Vilnius, tel. (8-5) 2103569, el. paštas - eglesatas@yahoo.co.uk.
} 
Šio straipsnio tikslas - išanalizuoti taikos atstatymo operacijų koncepciją ir naudojamas priemones, mechanizmus taikos operacijose. Taikos misijų vertinimas nėra šio straipsnio objektas. Pirmojoje straipsnio dalyje analizuojama kaip terminas taikos atstatymo operacijos naudojamas Jungtinių Tautu, Europos Sajungos, ESBO ir NATO. Šios dalies tikslas yra parodyti šių tarptautiniu organizacijų naudojamą terminologiją analizuojamai koncepcijai išreikšti, ir koks yra šio termino turinys. Antrojoje dalyje analizuojamos taikos atstatymo operacijos Bosnijoje ir Hercegovinoje didžiausią dėmesį skiriant taikos atstatymo mechanizmams, kuriuose naudojo ir dar tebenaudoja JT, NATO, ESBO ir ES. Bosnijos ir Hercegovinos atvejis pasirinktas dèl aktualumo ES ir Europos saugumui apskritai ir dèl ypatingos šios šalies politinès sistemos, sukurtos Deitono taikos sutartimi. Straipsnio autorès nuomone, Bosnijos ir Hercegovinos stabilumas yra vienas stabilumo visame Balkanų regione kertinių akmenų.

\section{Taikos atstatymo operacijų termino evoliucija ir turinys}

\section{1. Taikos atstatymo operacijos Jungtinių Tautų darbotvarkèje}

Jungtiniu Tautu politikos darbotvarkejje terminas taikos atstatymo operacijos atsirado tik $1992 \mathrm{~m}$. paskelbus Taikos darbotvarke $e^{1}$. Šioje generalinio sekretoriaus ataskaitoje be kitu jau tradicinėmis tapusiu JT funkcijų - prevencinès diplomatijos, taikdarystės ir taikos palaikymo operacijų ${ }^{2}$ - pirmą kartą buvo aptarta ir sąvoka taikos atstatymo operacijos. Darbotvarkëje buvo teigiama, kad vienas iš JT tikslų turi būti atstatyti konfliktų ar civilinio karo metu valstybių sugriautas institucijas ir infrastruktūrą bei pačia plačiausia prasme atsiliepti tinkamomis priemonemis ị konflikto priežastis: ekonominį nusivylimą, socialinę ir politinę nelygybę. Visa tai tapo taikos atstatymo operaciju bendraisiais uždaviniais.

Jungtinès Tautos suvokia taikos atstatymo operacijas kaip veiksmus, kuriais įtvirtinami taikdarystės ir taikos palaikymo operacijų uždaviniai. Taikos darbotvarkeje įvardintos tokios galimos taikos atstatymo operacijų priemonės: konfliktavusių pusių nuginklavimas ir tvarkos atstatymas, ginklų saugojimas

\footnotetext{
${ }^{1}$ An Agenda for Peace, Preventive diplomacy, peacemaking and peace-keeping, http://www.un.org/Docs/ SG/agpeace.html, 20080814.

2 Taikos darbotvarkeje šios sąvokos aiškinamos taip: „Preventive diplomacy - is action to prevent disputes from arising between parties, to prevent existing disputes from escalating into conflicts and to limit the spread of the latter when they occur; Peacemaking - is action to bring hostile parties to agreement, essentially through such peaceful means as those foreseen in Chapter VI of the Charter of the United Nations; Peace-keeping is the deployment of a United Nations presence in the field, hitherto with the consent of all the parties concerned, normally involving United Nations military and/or police personnel and frequently civilians as well. Peace-keeping is a technique that expands the possibilities for both the prevention of conflict and the making of peace“. Daugiau žr. Ulozevičiūte Ž., „Lietuvos dalyvavimas tarptautinèse taikos operacijose: narystès NATO ir ES iššūkiai“, Lietuvos metinè strateginè apžvalga 2004, p. 215-228.
} 
ir/arba sunaikinimas, pabėgèlių sugrąžinimas, saugumą užtikrinančio personalo mokymas ir parama patarimais, rinkimų priežiūra, rūpinimasis žmogaus teisių apsauga, vyriausybinių institucijų reforma ir/arba stiprinimas, formalių ir neformalių dalyvavimo politikoje procesų sukūrimas.

Karo tarp kelių valstybių atveju JT rekomenduoja imtis ne tik ekonominiu ir socialiniu projektu, tačiau stiprinti ir pasitikëjimą tarp anksčiau konfliktavusių valstybių, pvz., gerinti kelionių sąlygas, skatinti kultūrinius mainus, jaunimo ir edukacinius projektus arba tiesiog gerinti tokių resursų kaip elektra ir vanduo transportavimą.

Taip pat Taikos darbotvarkëje pabrěžiama, kad taikos atstatymas turi būti suvokiamas kaip neatsiejama prevencinès diplomatijos dalis, o kai konfliktas įsiplieskia ir panaudojamos taikdarystès priemonès arba vykdomos taikos palaikymo operacijos, vèliau turi sekti ekonomines, socialines, kultūrines ir humanitarines problemas sprendžiantys projektai, o tai ir yra taikos atstatymo operacijos.

Po dviejų metu pasirodžiusioje Vystymosi darbotvarkeje dar labiau išplètota taikos atstatymo operacijų koncepcija, tokios operacijos laikomos vienu iš vystymo pagrindų. Taikos atstatymas susiejamas su ekonominiu, socialiniu, kultūriniu vystymu. Taikos palaikymo operaciju priemonės suprantamos kaip „veiksmai, kuriais identifikuojamos ir palaikomos struktūros, kurios stiprina bei konsoliduoja taiką ir užtikrina, kad konfliktas neatsinaujintų“3. Darbotvarkëje teigiama, kad taikos atstatymo operacijų uždaviniai gali būti: nauju politiniu, socialiniu, teisinių institucijų kūrimas arba jau esančių sustiprinimas, žemės reforma ir panašūs socialinį teisingumą galintys atkurti žingsniai, demobilizacija ir gynybos reforma. Taip pat teigiama, kad vienas pirmujų taikos atstatymo operacijų uždaviniu turètų būti maisto tiekimas, parama sveikatos sistemai, teritorijų išminavimas ir logistinė parama konflikto vietoje esančioms organizacijoms. Dar vienas svarbus taikos atstatymo operacijų uždavinys turètų būti buvusių konflikto dalyviu, kurie paprastai rekrutuojami labai jauno amžiaus, integravimas į visuomenę.

Tačiau tiek Taikos darbotvarkëje, tiek Vystymosi darbotvarkejje taikos atstatymo operacijos siejamos su regionų atstatymu po konflikto. Pavyzdžiui, Vystymosi darbotvarkëje teigiama, kad prevencinès diplomatijos užduotis yra užtikrinti, kad konfliktas neįsipliekstu, o taikos atstatymo operacijų tikslas sudaryti sąlygas, kad konfliktas neatsinaujintų ${ }^{4}$. Tačiau jau 1995 m. pasirodžiusiame Supplement to an Agenda For Peace yra teigiama, kad taikos atstatymo operacijos gali būti ir prevencinès diplomatijos dalis - „nuginklavimas, smulkiujų ginklu kontrolè, institucinė reforma, policijos ir teisès sistemų gerinimas, žmogaus teisių priežiūra, rinkimų reforma bei ekonominis ir socialinis vystymasis gali būti veiksmingos priemonès ir užkertant kelią konfliktams, ir užgydant žaizdas po konflikto ${ }^{\prime \prime}$.

\footnotetext{
3 An Agenda for Development, http://daccessdds.un.org/doc/UNDOC/GEN/N94/209/22/IMG/N9420922. pdf?OpenElement, 20080814.

4 Ten pat.

5 Supplement to an Agenda For Peace: Position Paper of the Secretary-General on the Occasion of the Fiftieth Anniversary of the United Nations, http://www.un.org/Docs/SG/agsupp.html.
} 
Po JT taikos operacijų nesėkmių Ruandoje ir Somalyje 2000 m. pasirodžiusioje vadinamojoje Brahimi ataskaitoje pirmą kartą atkreiptas dèmesys, kad taikos atstatymo mechanizmai gali būti naudojami ne tik pokonfliktinèse fazèse. Tuo metu tokias priemones pasiūlyta panaudoti kaip papildomas taikos operacijose Tadžikistane ir Haityje, ir kaip nepriklausomas iniciatyvas Gvatemaloje ir Bisau Gvinejjoje ${ }^{6}$. Kadangi Brahimi ataskaitos tikslas buvo įvertinti JT taikos operacijas ir pateikti rekomendacijas, taikos atstatymo operacijos buvo ne išimtis. Pasak ataskaitos rengèju, daugiau reikšmės turi būti teikiama tokioms priemonėms kaip parama rinkimuose, reformos, policijos sistemos pertvarkymas ir restruktūrizacija, kariuomenès, policijos ir civilio personalo mokymas žmogaus teisių ir tarptautinès teisès taikymo klausimais, taip pat nusiginklavimas, demobilizacija ir buvusių kovotojų reintegracija ${ }^{7}$. Brahimi ataskaita pabrèžė visų keturių koncepciju - prevencinės diplomatijos, taikos kūrimo, taikos palaikymo operacijų ir taikos atstatymo - naudojimą JT darbotvarkëje ir praktikoje tiek apimties, tiek svarbos prasme.

2005 m. generalinis sekretorius paskelbė ataskaitą In Larger Freedom. Joje taip pat buvo analizuojami taikos operaciju klausimai. Kofis Annanas turèjo pripažinti, kad tarpininkavimas ir taikos susitarimu igyvendinimas nebuvo sèkmingas keletu atveju XX a. paskutiniajame dešimtmetyje, ir tokios valstybès kaip Angola, Ruanda ir Somalis vèl įsitraukè į konfliktus. Jis pabrèžè, kad:

jei mes norime užkirsti kelią konfliktams, turime užtikrinti, kad taikos susitarimai būtų igyvendinami laiku ir ilgam. Šiuo aspektu Jungtinių Tautų institucinejje struktūroje yra trūkumų: nẻ viena iš Jungtinių Tautų sistemos dalių efektyviai nepadeda valstybėms pereiti nuo karo į ilgalaikę taiką. Todèl aš siūlau valstybėms narėms sukurti tarpvyriausybinę Taikos atstatymo komisiją, taip pat Paramos taikos palaikymui biurą JT sekretoriate ${ }^{8}$.

Po kelių mėnesių generalinis sekretorius paskelbė dokumentą Explanatory Note ${ }^{9}$. Jame apibrèžti Taikos atstatymo komisijos tikslai ir funkcijos. Pagal ši dokumentą ir Generalinès Asamblëjos rezoliuciją Nr. $1645^{10}$, Komisija turi dirbti su konfliktų prevencija ir pokonfliktinių regionų atstatymu: „teikti reikalingą informaciją Saugumo Tarybai ir demesį skirti vystymuisi ir instituciju kūrimui, kurie yra reikalingi, kad šalis atsigautų “11. Komisija veikia per tris

${ }^{6}$ Report of the Panel on United Nations Peace Operations, http://daccessdds.un.org/doc/UNDOC/GEN/ N00/594/70/PDF/N0059470.pdf?OpenElement, 20080816.

7 Ten pat.

8 In Larger Freedom: towards development, security and human rights for all, http://daccessdds.un.org/doc/ UNDOC/GEN/N05/270/78/PDF/N0527078.pdf?OpenElement, 20080817.

9 Explanatory Note by Secretary-General on the Peace building Commission, Addendum to Report of the Secretary-General, In larger freedom: towards development, security and human rights for all, http:// daccessdds.un.org/doc/UNDOC/GEN/N05/356/07/PDF/N0535607.pdf?OpenElement, 20080818.

${ }^{10}$ Pagal rezoliuciją Nr. 1645, Komisijos tikslai yra: kviesti visus suinteresuotus veikejjus prisidèti resursais ir siūlyti integruotas strategijas pokonfliktiniam taikos atstatymui ir regiono atsigavimui; užtikrinti finansavimą ankstyvo atstatymo veiksmams ir finansines laikotarpio investicijas ilgesniam ir trumpesniam laikui; nustatyti geros praktikos pavyzdžius, dirbant su politiniais, saugumo, humanitarinès pagalbos ir plètros veikèjais.

${ }^{11}$ Ten pat. 
pagrindines savo institucijas - Organizacinį komitetą, susitikimus dèl atskiru šalių ir darbo grupę išmoktoms pamokoms - bei užtikrina resursus, ir teikia strategijas atstatymui po konflikto. Pagal rezoliuciją Nr. 1645, Organizacinį komitetą sudaro 31 šalis narè: septyni nariai renkami Saugumo Tarybos ${ }^{12}$, septyni nariai išrinkti Ekonominès ir socialinès tarybos ${ }^{13}$, penki didžiausi JT biudžeto, JT fondų, programų ir agentūru, įskaitant ir nuolatinį taikos atstatymo fondą, kontributoriai ${ }^{14}$, penkios daugiausia karinio ir civilio personalo JT misijoms teikiančios šalys ${ }^{15}$ ir septyni nariai, išrinkti Generalinès Asamblëjos ${ }^{16}$. Pagrindinè Organizacinio komiteto funkcija yra sudaryti darbotvarkę, įskaitant ir vidutinès trukmès, ir integruotas taikos atstatymo strategijas. Specifinių šaliu susitikimuose analizuojami atskiros šalies klausimai. Šiuo metu trys šalys Burundis, Bisau Gvinëja ir Siera Leonè - yra JT darbotvarkèje.

Tai, kad JT kreipia ypatingą dėmesį taikos atstatymui, liudija ir faktas, kad kartu su Taikos atstatymo komisija buvo įsteigtas Taikos atstatymo fondas ir Taikos atstatymo paramos biuras.

JT Taikos atstatymo fondas buvo sukurtas 2006 metu spali, kai Saugumo Taryba ir Generalinė Asamblëja pareikalavo vykdyti taikos atstatymo operaciju priemones. Fondo tikslas yra remti tiesioginius ir skubius veiksmus, kurie yra taikos atstatymo operacijų dalis, ir ypač tuomet, kai negalima taikyti jokiu kitų mechanizmų ${ }^{17}$. Fondo vaidmuo yra iggyvendinti taikos susitarimus, šaliu pastangas stiprinant ir kuriant pajëgumus, kurie padètų išspręsti konfliktą, esamų administracinių gebëjimų bei techninių ir žmogiškujų resursų sukūrimą arba atkūrimą, dalyvauti intervencijose, kuriomis siekiama atsakyti i̇ taikos atstatymo operacijoms kylančias grèsmes (pvz., buvusiu kovotoju, kurie buvo nuginkluoti pagal nusiginklavimo, demobilizacijos ir reintegracijos programas, reintegravimas) ${ }^{18}$. Taikos atstatymo fondo biudžetas skirstomas į tris dalis: i pirmająa iš biudžeto finansuojamų valstybiu grupę patenka tos šalys, kurios yra Taikos atstatymo komisijos darbotvarkejje, i antrają -JT generalinio sekretoriaus priskirtos valstybės, o ypatingais atvejais Fondas gali skirti lëšuz, jei to prašo JT igaliotasis atstovas šalyje. 2008 metų rugsèjį keturios šalys - Burundis, Centrinès Afrikos Respublika, Bisau Gvinejja ir Siera Leonè - gavo paramą iš Taikos atstatymo fondo kaip pirmajai grupei priklausančios šalys; Komorai, Dramblio Kaulo Respublika, Gvinejja, Liberija ir Nepalas gavo pinigines lëšas kaip antros grupės valstybės, trečiai grupei priklausė Burundis, Centrinės Afrikos Respublika, Dramblio Kaulo Respublika, Gvinejja, Haitis, Liberija ir Kenija ${ }^{19}$.

Tačiau vis dèlto, kaip teigia Jennifer M. Hazen straipsnyje „Can Pea-

\footnotetext{
122008 metais - Belgija, Kinija, Prancūzija, Rusijos Federacija, Pietų Afrika, Jungtinè Karalystė ir JAV.

${ }^{13} 2008$ metais - Angola, Brazilija, Čekija, Bisau Gvinejja, Indonezija, Liuksemburgas ir Šri Lanka.

${ }^{14} 2008$ metais - Kanada, Vokietija, Japonija, Nyderlandai ir Švedija.

${ }^{15} 2008$ metais - Bangladešas, Gana, Indija, Nigerija ir Pakistanas.

${ }^{16} 2008$ metais - Burundis, Čilè, Egiptas, Salvadoras, Fidžis, Gruzija ir Jamaika.

${ }^{17}$ Peacebuilding Fund: Terms of Refference, http://www.unpbf.org/beta/docs/TOR.pdf, 20080820.

${ }_{18}^{18}$ Ten pat.

${ }^{19}$ United Nations Peace-building Fund, Bulletin No. 4, http://www.unpbf.org/index.shtml, 20080820.
} 
cekeepers be Peacebuilders ${ }^{\prime 20}$, taikos atstatymo operacijos Jungtinėse Tautose taip ir liko beformè koncepcija - be aiškių tikslų ir uždavinių, nes labai dažnai taikos palaikymo operacijų uždaviniai, pvz., institucijų reforma, betarpiškai susiję su taikos atstatymo operacijų tikslais, o ir pačios Jungtinės Tautos skelbia, kad taikos atstatymo operacijos turi būti integrali taikos palaikymo operacijų dalis.

\section{2. Europos Sajunga ir civilinis krizių valdymas}

ES pareiškia norą įsitraukti į taikos operacijas nuo 1998 m., po susitarimo Sent Malo, kai po tragedijos Bosnijoje Jungtinė Karalystė ir Prancūzija ėmè keisti savo poziciją dèl bendros saugumo ir gynybos politikos ES. Buvo konstatuota, kad ES turi vaidinti visapusišką vaidmenį tarptautinëje arenoje ir todèl, buvo teigiama, „Europos Sajunga privalo turèti veiksmų autonomiją, paremtą patikimomis karinėmis pajėgomis, priemones, turinčias teisę nuspręsti dẻl pajègu panaudojimo ir, norèdama atsiliepti į tarptautines krizes, turi būti pasiruošusi tai padaryti“ “21. ES šis procesas prasidejjo 1999 metais Europos viršūnių tarybos susitikime Kelne, kada Kosovo krizės akivaizdoje šalys narės pritarè Sen Malo susitarimo idèjai. Tų pačių metų Europos viršūnių taryboje Helsinkyje narès susitarė dèl karinių pajėgumų vystymo - Pagrindinio tikslo 2003, o $2001 \mathrm{~m}$. Geteborge valstybès pradèjo diskusijas dèl civilinių pajègumų.

Ir kariniai, ir civiliniai pajègumai vystomi, atsižvelgiant į ES sutarties 17.2 straipsniu nustatytas misijas, dar vadinamas Petersbergo užduotimis - humanitarinès ir gelbejjimo užduotys, taikos palaikymo operacijos, kovinių pajègu misijos, įskaitant ir taikdarystę. Tačiau, kaip teigia Jean - Yves Haine'as, yra keletas įtikinamu šios teisinès formuluotès interpretaciju, kaip, pavyzdžiui, kad 1999 m. Kelne buvo susitarta, jog į ši užduočių sąrašą įeina „plataus spektro konfliktų prevencijos ir krizių valdymo operacijos“22. Taigi ES veiksmai gali igauti pačias įvairiausias formas, Martino Ortega žodžiais, „nuo pačiu kukliausių iki pačių sudètingiausių “23. Europos saugumo strategijoje buvo plačiau išaiškinta, kokio tipo taikos operacijose ES galètų dalyvauti. Strategijoje identifikuotos penkios pagrindinès grèsmès: terorizmas, masinio naikinimo ginklų platinimas, regioniniai konfliktai, žlungančios valstybės ir organizuotas nusikalstamumas. ES valstybės narès taip pat pabrèžè, kad:

${ }^{20}$ Hazen J. M., „,Can Peacekeepers be Peace-builders?“, International Peacekeeping, vol. 14., no. 3, 2007 , p. 324.

${ }^{21}$ „British-French summit St-Malo, 3-4 December 1998, From St-Malo to Nice, European defence: core documents“, Chaillot Paper 47, May 2001, p. 8-9, http://www.iss.europa.eu/uploads/media/cp047e.pdf, 20080821.

${ }^{22}$ Haines J. Y., „An Historical Perspective“ in Gnesotto N., ed., EU Security and Defence Policy, The First Five Years (1999-2004), p. 44, http://www.iss.europa.eu/uploads/media/5esdpen.pdf, 20080821.

${ }^{23}$ Ortega M., ,Beyond Petersberg: missions for the EU military forces“ in Gnesotto N., ed., EU Security and Defence Policy. The First Five Years (1999-2004), p. 74, http://www.iss.europa.eu/uploads/media/5esdpen. pdf, 20080821. 
Mūsų tradicinis savigynos supratimas, vyravęs iki Šaltojo karo laikotarpio imtinai, buvo grindžiamas invazijos grèsme. Atsiradus naujoms grèsmėms, pirmoji gynybos linija dažnai bus kitur nei Europoje. Naujos grèsmės yra dinamiškos. Pavojai, susiję su masinio naikinimo ginklų platinimu, per laiką auga; teroristų tinklai, ị juos nekreipiant dėmesio, taps vis pavojingesni. Nekreipiant dèmesio į atitinkamus veiksnius, valstybės žlugimo atvejų daugès ir organizuotas nusikalstamumas išplis; tai jau matėme Vakarų Afrikoje. Tai reiškia, kad turètume būti pasirengę veikti krizei dar neprasidejus. Niekada nebus per anksti vykdyti konfliktu ir grèsmiu prevenciją ${ }^{24}$ [pabraukta mano - EEŠ].

Haine'o nuomone, tai reiškia, kad Sajunga yra pajègi dalyvauti stabilizavimo ir taikos atstatymo misijose ${ }^{25}$. ES atveju tai yra taikos atstatymo mechanizmu, tokių kaip policijos ir/arba civilinès administracijos personalo, $\mathrm{ir} /$ arba civilių apsaugos pajėgumu, panaudojimas.

Karinių pajėgumų klausimu valstybės narès susitarè, kad Petersbergo užduotims igyvendinti iki 2003 metu pabaigos jos bus pajègios per 60 dienu dislokuoti 50.000 - 60.000 karių, kurie misiją galès vykdyti mažiausiai metus. 2001 metais Lakene valstybės narès paskelbè, kad jau gali vykdyti kai kurias krizių valdymo operacijas ${ }^{26}$. Šis pareiškimas buvo sustiprintas $2003 \mathrm{~m}$. Bendruju reikalų ir išorès santykių taryboje bei 2003 m. Europos viršūnių taryboje Salonikuose, kada buvo konstatuota, kad „ES dabar jau turi operacinius pajėgumus visoms Petersbergo užduotims vykdyti, kurie varžomi tik kai kurių trūkumu, tačiau pastarieji yra identifikuoti“27. Pabrèždama, kad pajėgų sąveikumas (angl. interoperability), parengtis (angl. deployability) ir patvarumas (angl. sustainability) turi būti šalių narių dėmesio centre ir turèdama omenyje Europos saugumo strategiją, Europos vadovu taryba Briuselyje $2004 \mathrm{~m}$. patvirtino Pagrindinị tiksla 201028. Svarbiausias Pagrindinio tikslo 2010 elementas yra greitojo reagavimo pajègų sukūrimas, tai leistų ES dalyvauti plataus spektro krizių valdymo operacijose, kaip ir numato ES steigimo sutartis. Greitojo reagavimo pajėgu koncepcija buvo aptarta dar Helsinkyje kaip svarbi ES krizių valdymo pajėgumų dalis, o po sèkmingos Artemis misijos 2003 m. liepą prasidejo jos igyvendinimas. 2007 m. sausio $1 \mathrm{~d}$. paskelbta, kad ES kovinès grupès visiškai paruoštos misijoms. Kovinė grupė yra efektyvus, patikimas, greitai dislokuojamas, koherentinis karinis vienetas, galintis vykdyti savarankiškas operacijas arba gali būti naudojamas pradinëje didesnių misijų fazèje. Kovinę grupę sudaro apie 1500 karių. Grupè gali vykdyti misiją ne mažiau kaip 30 dienu, jei papildomai aprūpinama - iki 120 dienų. Kovinės grupės vykdys Petersbergo užduotis bei Europos saugumo

\footnotetext{
${ }^{24}$ Saugi Europa geresniame pasaulyje, Europos saugumo strategija, p. 7, http://ue.eu.int/uedocs/ cmsUpload/031208ESSIILT.pdf, 20080801.

${ }^{25}$ Haines, (nuoroda 22) p. 51.

${ }^{26}$ Council of the European Union, Presidency Conculsions, European Council Meeting in Laeken, 14-15 December 2001, http://www.consilium.europa.eu/ueDocs/cms_Data/docs/pressData/en/ec/68827.pdf, 20080822.

${ }^{27}$ Council of the European Union, Presidency Conclusions, Thessaloniki European Council, 19-20 June 2003, http://www.consilium.europa.eu/ueDocs/cms_Data/docs/pressData/en/ec/76279.pdf, 20080822.

${ }^{28}$ Europos Sajungos taryba, Pirmininkaujančios valstybès išvados, Europos vadovu taryba, 2004 m. liepos 17-18 d., http://www.consilium.europa.eu/ueDocs/cms_Data/docs/pressData/LT/ec/81758.pdf, 200808 22.
} 
strategijoje nustatytus prioritetus, ypač jei tai susiję su kovinių pajėgų panaudojimu valdant krizes. Pajègumų vystymo proceso metu ES parenge penkis iliustracinius Kovinès grupės panaudojimo scenarijus: konfliktų prevencija, konfliktuojančiu grupių atskyrimas jèga, stabilizavimas, rekonstrukcija ir karinių patarimų teikimas trečiosioms šalims, evakuacijos užduotys ir pagalba humanitarinėse operacijose ${ }^{29}$. Kovinès grupès paprastai yra karinio ES krizių valdymo komponento dalis, tačiau kartu joms priskiriami ir taikos atstatymo uždaviniai: konfliktų prevencija, rekonstrukcija ir kariniai patarimai.

Jei kalbètume apie civilinį krizių valdymo komponentą, galimybė sukurti ir dislokuoti civilinę policijos misiją buvo diskutuota dar Helsinkyje. Vèliau 2000 m. Feiroje šalys narès įvardijo keturias prioritetines sritis, kuriose Sajunga turi vystyti savo pajėgumus. Tai policijos bendradarbiavimas, teisès viršenybė, civilinè administracija ir civilių sauga. Feiroje šalys narès buvo paragintos iki 2003 m. būti pasirengusios dislokuoti iki 5000 policijos darbuotojų (iš kurių iki 1000 per 30 dienų) $)^{30} .2001 \mathrm{~m}$. Europos viršūnių susitikime Geteborge susitarta dèl Civilinio pagrindinio tikslo 2003. Susitikimo metu nustatyti konkretūs uždaviniai likusių trijų civiliniu pajègumu plètotei užtikrinti. Šalys narès įsipareigojo teisės viršenybės misijoms skirti 200 pareigūnų (prokuroru, teisėju, kalejjimo pareigūnų). Tokiomis misijomis siekiama ištaisyti teisinės sistemos trūkumus šalyse, kuriose, pavyzdžiui, nekompetentingi teisèjai, įsigalëjusi korupcija ir / arba teisès aktai neatitinka tarptautinių standartų, ypatingai žmogaus teisių srityje, ir tai kelia grèsmę tarptautinei taikai ir saugumui. Tokių misijų metu teisès sistemos personalas netgi gali būti pakeistas tarptautiniais teisèjais, teismo pareigūnais, teisès ekspertais, ir ju pagalbiniu personalu, tačiau tai jau paskutine iš visu priemonių. Labiau tikètina, kad ES prisidès prie teisès sistemos funkcionavimo pagerinimo ir dèmesį skirs stebejjimui, patarimams, pareigūnu mokymams bei padès vyriausybei reformuoti teisès sistemą ir teisès aktus ${ }^{31}$. Pavyzdžiui, ES misija Gruzijoje EUJUST THEMIS padejjo sukurti strategiją Gruzijos baudžiamosios teisės reformai. Dẻl civilių administracijos dalies šalys narès įsipareigojo skirti ekspertus, galinčius vykdyti civilinės administracijos misijas civilinių krizių valdymo operacijose ir, jei tai reikalinga, dislokuojamiems per itin trumpą laikotarpi. Civilinès administracijos misijų funkcijos gali būti rinkimų organizavimas, švietimo paslaugų teikimas, geriamo vandens užtikrinimas ir pan. Civilių saugos instrumentą sudaro trys dalys: a) 2 arba 3 koordinavimo ir/arba vertinimo grupės, kurias galima mobilizuoti per para, susidedančios iš 10 ekspertų ir kuriuos galima išsiųsti per 3-7 val., b) intervencinès komandos, kurias sudaro iki 2000 asmenu; c) papildomos arba labiau specializuotos komandos, kurias galima išsiųsti per 2-7 dienas, atsižvelgiant i k konkrečius poreikius. Civilių saugos misijų uždaviniai yra dirbti su gamtos,

\footnotetext{
${ }^{29}$ EU Council Secretariat, Factsheet, EU Battlegroups, February 2007, http://www.consilium.europa.eu/ uedocs/cmsUpload/Battlegroups_February_07-factsheet.pdf, 20080823.

${ }^{30}$ Council of the European Union, Presidency Conclusions, Santa Maria da Feira European Council, 19-20 June 2000, http://www.consilium.europa.eu/ueDocs/cms_Data/docs/pressData/en/ec/00200-r1.en0.htm, 20080823.

${ }^{31}$ Merlingen M., Ostrauskaite R., European Union Peacebuilding and Policing, Routledge, 2006, p. 47.
} 
technikos, aplinkos sukeltų katastrofų aukomis. Civilių saugos mechanizmai taip pat gali būti panaudoti, remiant ES vykdomas paieškos ir gelbëjimo operacijas, įrengiant pabėgèlių stovyklas ir teikiant humanitarinę pagalbą ${ }^{32}$. Šiandien ES šalys narès gali siųsti i̇ misijas 5761 policijos pareigūną, 631 pareigūną teisès viršenybès funkcijai, 565 pareigūnus civilinès administracijos operacijoms, 579 civilių saugos ekspertus ir 4445 pareigūnus intervencinėms komandoms civilių saugos užduotims ${ }^{33}$.

Politikos ir saugumo komiteto (toliau - PSK) prašymu ES Tarybos sekretoriatas dirbo prie stebejjimo misijų koncepcijos ir platesnio naudojimo. Šis klausimas tapo svarbus po ES stebejjimo misijos Balkanuose. 2003 m. gegužę PSK parengè ES stebëjimo misijų koncepciją. Pagal ją, stebejjimo operacijos yra integruota dalis ir gali būti panaudojama įvairiose krizių valdymo fazèse - konfliktų prevencija/sprendimas ir/arba krizių valdymas ir/arba taikos atstatymas - ir „kurios pagrindinis tikslas bus stebėti ir pranešti siunčiančiai organizacijai apie bendrą ir saugumo situaciją šalyje arba apie situaciją, kurią lemia pasiektas specifinis susitarimas “34. Tai taip pat apima tokius veiksmus kaip prisidejimas prie pasitikẻjimo stiprinimo, žemo intensyvumo konfliktų sprendimas, pabėgèlių sugrižimo priežiūra, žmogaus teisių, nusiginklavimo ir demobilizacijos, sienų monitoringas, teisės viršenybės klausimai. ES šalys narès yra parengusios 505 pareigūnus šioms misijoms vykdyti.

Petersbergo užduočių vykdymas priskirtas specialioms ESGP institucijoms ir mechanizmams. Pagrindiniai politiniai sprendimai priimami Europos Vadovų Taryboje ir Bendrujų reikalų ir išorès santykių taryboje (toliau - Bristas). Helsinkyje taip pat įsteigtos trys naujos institucijos - Politikos ir saugumo komitetas, ES karinis komitetas ir ES karinis štabas. PSK yra pagrindinè sprendimu modeliavimo institucija, bet, kaip pažymi Antonio Missiroli, komiteto sprendimu priėmimo funkcija yra ribota, nes priimant politinius / strateginius sprendimus, remiamasi Bristo nuomone, o finansiniai BUSP/ESGP aspektai vis dar yra COREPER reikalas ${ }^{35}$. PSK svarstomi visi kariniai ir civiliniai kriziu valdymo reikalai. Komitetas taip pat palaiko ryšį su vyriausiuoju igaliotiniu BUSP ir ES specialiais atstovais, kad būtų užtikrinta visų ESGP misiju politinẻ kontrolè ir strategine kryptis. ES karinį komitetą sudaro gynybos vadai, kuriuos atstovauja nuolatiniai kariniai atstovai. Karinio komiteto funkcija yra teikti karinio pobūdžio patarimus PSK ir dalyvauti Tarybos posėdžiuose, kai priimami gynybinių implikacijų turintys sprendimai. ES karinis štabas yra Tarybos sekretoriato dalis ir veikia vadovaujant ES kariniam komitetui. Karinis

\footnotetext{
${ }^{32}$ Ten pat, p. 46-47.

${ }^{33}$ EU Council Secretariat, European Security and Defence Policy: the civilian aspects of crisis management, May 2007, http://www.consilium.europa.eu/uedocs/cmsUpload/Background_JPO_2007-Civilian_aspects_compressed.pdf, 20080823.

${ }^{34}$ Nowak A., „Civilian Crisis Management within ESDP“ in Nowak A., ed., Civilian Crisis Management: the EU Way, Chaillot paper 90, June 2006, p. 28, http://www.iss.europa.eu/uploads/media/cp090.pdf, 20080823.

${ }^{35}$ Missiroli A., „ESDP - How it works“ in Gnesotto N., ed., EU Security and Defence Policy, The First Five Years (1999-2004), p. 64, http://www.iss.europa.eu/uploads/media/5esdpen.pdf, 20080823.
} 
štabas teikia karinį vertinimą ir paramą, vykdant gynybos politiką, įskaitant ir krizių valdymo operacijų vykdymą, ankstyvą perspejjimą, situacijų vertinimą ir strateginį karinių Petersbergo užduočių aspektų planavimą.

Sprendimai dèl su civiliniu komponentu susijusių institucijų sukūrimo buvo priimti Europos Vadovų Taryboje Lisabonoje 2000 m. kovą. Šalys narès sutarè įsteigti Krizių valdymo civilinių aspektų komitetą (toliau - CIVCOM). Pagrindiné CIVCOM funkcija yra teikti patarimus PSK dèl civilinių ES ir jos valstybių narių vykdomų krizių valdymo užduočių aspektų. Tai tarpramstinė (angl. inter-pillar) institucija, kuri veikia vadovaujama COREPER ir pataria PSK dèl antrojo ramsčio vykdomos politikos ir šalių narių krizių valdymo misijų bei padeda užtikrinti sąsają tarp ramsčių ${ }^{36}$. CIVCOM taip pat veikia kaip informacijos dalijimosi ir veiksmų koordinavimo tarp ES ir jos narių mechanizmas, ir tokiu būdu užtikrina greitą reagavimą į krizes. Tačiau, kaip teigia Agnieszka Nowak, vis dèlto funkcija išlieka patariamojo pobūdžio - CIVCOM formuluoja rekomendacijas PSK, o pastaroji institucija atlieka pagrindinį vaidmenį sprendžiant, kokia turi būti ES reakcija ir tolimesnès priemonès, reaguojant $i$ krizes $^{37}$.

Stiprinant civilinę ESGP misiju pusę, 2005 m. neformaliame susitikime Hampton Korte ES valstybės narès susitarė įkurti Civilinį planavimo ir vykdymo pajègumu padalinị (toliau - CPVP) ir Civilinių operacijų vado postą. Šie du institutai laikomi civiliniu ES karinio štabo atitikmeniu. CPVP įurtas 2007 m. rugpjūti ir yra Tarybos sekretoriato dalis. CPVP turi mandatą planuoti ir vykdyti civilines ESGP misijas, kurių politinę kontrolę ir strateginės krypties nustatymą atlieka PSK bei teikti paramą ir rekomendacijas Vyriausiajam igaliotiniam BUSP, ES pirmininkaujančiai valstybei ir atitinkamoms ES tarybos sekretoriato institucijoms, taip pat vadovauti, koordinuoti, teikti rekomendacijas, kitokią paramą, prižiūrèti ir peržiūrèti civilines ESGP operacijas. CPVP direktorius kaip ES civilinių operacijų vadas vadovauja ir kontroliuoja strateginiame lygmenyje, kada planuojamos ir vykdomos visos civilinės krizių valdymo misijos, o politinę kontrolę ir strateginės krypties nustatymą tokiu atveju vykdo PSK, bendrai vadovauja vyriausiasis igaliotinis BUSP ${ }^{38} .2008 \mathrm{~m}$. rugsėjo mèn. duomenimis, CPVP atsakingas už devynias misijas policijos, sienų apsaugos, teisės viršenybės ir saugumo sektoriaus reformų srityse: EUPM (Bosnijoje ir Hercegovinoje); EULEX KOSOVO; EUPOL COPPS ir EUBAM Rafah (Palestinos teritorijose); EUJUST LEX (Irake); EUPOL Afghanistan; EUPOL RD Congo; EU SSR Guinea-Bissau (tai pirmoji misija, kurią planavo CPP) ir EUMM (Gruzijoje).

Reziumuojant reikia pabrèžti, kad ES nuveikè daug rengdama ir igyvendindama karinį ir civilinį krizių valdymo komponentus. Pastaruoju metu

\footnotetext{
${ }^{36}$ Preparatory document related to CESDP : Establishment of a European Union Committee for Civilian Crisis Management, http://www.consilium.europa.eu/uedocs/cmsUpload/Preparatory\%20document $\% 20$ CESDP\%20-\%20Committee.pdf.

${ }^{37}$ Nowak, (nuoroda 34) p. 23.

38 „Introducing CPCC“, ESDP newsletter, No. 6, July 2008, p. 24-45, http://www.consilium.europa.eu/ uedocs/cmsUpload/pages24-25-CEU8003ESDP6final_vers.pdf, 20080825.
} 
ES darbotvarkëje daug dėmesio skiriama civiliniu pajėgumų vystymui, pvz., buvo sukurtas CPVP ir Civilinis pagrindinis tikslas 2010. Pedro Serrano ${ }^{39}$ teigia, kad ES misijas galima skirstyti į šias kategorijas:

- stabilizavimas (karinès pajègos dislokuojamos tam, kad atskirtų konfliktuojančias puses arba įvestų taiką konflikto paveiktame regione; tokių operaciju pavyzdžiai yra Althea Bosnijoje ir Hercegovinoje ir Artemis Demokratineje Kongo Respublikoje);

- pakeitimas (tarptautiniu pajegu uždavinys yra perimti tiesioginį valdymą funkciju, kurias ịprastomis aplinkybèmis vykdo vietinè valdžia, pvz., saugumo sektoriuje (kariuomenė, policija), teisės viršenybės srityje (teismai, prokurorai, baudžiamoji sistema);

- stiprinimas arba reformos (tikslas - reformuoti, rekonstruoti, sukurti tam tikrą valdžios veiklos sritį monitoringo, patarimų ir inspektavimo pagalba; tai daroma gynyboje arba policijoje, taip pat gali būti vykdoma teisès viršenybės ir viešojo administravimo sferose; tokių misijų pavyzdžiai yra policijos misija Bosnijoje ir Hercegovinoje (EUPM), policijos misija Makedonijoje (Proxima), teisès viršenybès misija Gruzijoje (EUJUST THEMIS), policijos misija Demokratinejje Kongo Respublikoje (EUPOL Kinshasa));

- stebëjimas (susitarimo įgyvendinimo priežiūra, tokia misija, pavyzdžiui, buvo vykdoma Ačeho provincijoje Indonezijoje (Aceh Monitoring Mission (AMM)) ir yra vykdoma Palestinos teritorijoje (EU Border Assistance Mission at Rafah Crossing Point in the Palestinian Territories (EUBAM Rafah));

- parama krizių valdymo organizacijoms (JT, ESBO, Afrikos Sajungai ir kt.).

Reikia pastebèti, kad net iki šiol ES daugiausia vartoja vieną terminą civilinis krizių valdymas - apibūdinti visas ES personalui keliamas užduotis. Civilinis krizių valdymas apibūdinamas kaip civilio personalo intervencija ị krizę, turint tikslą užkirsti kelią jo eskalavimui ir jį išspręsti. Civiliniai ir netgi kariniai ES pajėgumai, pvz., ES kovinès grupès, dabar jau turi uždavinị įsitraukti i taikos atstatymo misijas, nes tokios operacijos suprantamos kaip priemonès kelio krizèms kilti užkirtimas. Pirmą kartą šis klausimas buvo aptartas apskrito stalo diskusijoje Vašingtone $2001 \mathrm{~m}$. Po diskusijos išleistoje ataskaitoje European Approaches to Civilian Crisis Management ${ }^{40}$ Chrisas Lindborgas pažymi, kad ekspertai akcentavo skirtumą tarp "konfliktų prevencijos“ - veiksmu, kuriu imamasi prieš įsiplieskiant bet kokiems neramumams - ir "krizių valdymo“ intervencijos, kada kyla kariniai veiksmai. Naudojant JT terminologiją, ES turi

\footnotetext{
${ }^{39}$ Serrano P., ,A Strategic Approach to the European Security and Defence Policy“ in Nowak A., ed., Civilian Crisis Management: the EU Way, Chaillot paper 90, June 2006, p. 39-43, http://www.iss.europa.eu/ uploads/media/cp090.pdf, 20080823.

${ }^{40}$ European Approaches to Civilian Crisis Management, A Basic Special Report on Roundtable Discussions Held in Washington, D.C., October 2001, British American Security Information Council, 2002, http:// www.basicint.org/pubs/Research/2002ccm.pdf, 20080826.
} 
įsitraukti į prevencinės diplomatijos ir taikdarystės veiksmus. Lindborgas taip pat teigia, kad „taikos atstatymo operacijos, vykdomos konfliktui pasibaigus, yra dar viena priemonè, galinti padèti užkirsti kelią konfliktams įsiplieksti“, ir todèl dažnai tampa diskusijų dèl civilinio krizių valdymo dalimi. Lindborgas daro išvadą, jog civilinis krizių valdymas „susideda iš keleto dalių ir veikëju, o ribos tarp civilinio krizių valdymo ir konfliktu prevencijos iš vienos pusès bei civilinio ir karinio kriziu valdymo iš kitos nèra aiškiai nubrěžtos".

Žiūrint ị ES ịvykdytas ir vykdomas misijas, galima daryti išvadą, kad ES demesi skiria preventyviems veiksmams ir taikos atstatymo misijoms. Šiandien ES vykdo 12 misijų Vakarų Balkanuose (3 misijos), Pietų Kaukaze (1 misija), Artimuosiuose Rytuose (3 misijos), Azijoje (1 misija) ir Afrikoje (4 misijos) ${ }^{41}$. Iš ju 8 misijos yra civilinès (EUPM Bosnijoje ir Hercegonijoje, EULEX KOSOVO, EUMM Gruzijoje, EUPOL COPPS Palestinos teritorijoje, EU BAM Rafah Palestinos teritorijoje, Eujust Lex Irake, EUPOL AFGHANISTAN, EUPOL RD CONGO), 2 - karinès (EUFOR-Althea, EUFOR TCHAD/RCA) ir 2 karinès - civilinès (EU SSR Guinea-Bissau, EUSEC RD Congo). Beveik visos civilinès ES misijos yra taikos atstatymo misijos. Misijos EUPOL RD Congo tikslas yra padèti Kongo policijai jai vykdant reformas ir taip pat tose srityse, kuriose policija veikia kartu su visa teisine sistema. Šiuo metu misijoje tarnauja 39 tarptautiniu pajėgu pareigūnai, jiems padeda 9 vietinio personalo nariai. EUPOL Afghanistan nori prisidèti prie efektyvios ir tarptautinius standartus atitinkančios policijos, kuriai vadovautu patys afganai, sistemos sukūrimo. ES misijos metu stebi, pataria ir moko vietinius pareigūnus Afganistano vidaus reikalu ministerijoje, regionuose ir provincijose. Misijos pajègumai - 184 tarptautiniai ir 90 vietiniu pareigūnu. EUJUST LEX Irake moko ir suteikia galimybes tobulintis vyriausiems Irako teismų, kalejimų ir policijos pareigūnams. Neseniai pradèta vykdyti ES misija Gruzijoje EUMM taip pat yra vienas hipotezę, kad civilinės ES misijos yra taikos atstatymo operacijos, patvirtinančiu pavyzdžių. Po to, kai Rusija ir Gruzija pasiekė susitarimą, ES pasiuntė 200 civilių stebėtoju kontroliuoti ir analizuoti situaciją.

\subsection{Taikos atstatymo operacijos NATO}

NATO itin abstrakčiai apibrèžia, kokio tipo misijose organizacija turètu dalyvauti. Šaltojo karo metu pagrindinis NATO tikslas buvo užtikrinti, kad Aljansas turètu pajègumus vykdyti kolektyvinio saugumo operacijas pagal Šiaurès Atlanto sutarties 5 straipsnị. Po Šaltojo karo Aljansas ịsitraukè į konfliktu prevenciją, taikos atstatymo ir ịtvirtinimo operacijas, pavyzdžiui, buvusios Jugoslavijos Federacijos teritorijoje, Afganistane ir Irake. NATO vykdomos operacijos skirstomos ị du tipus: atsako ị krizes operacijos (angl. crises response operations) ir taikos palaikymo operacijos (angl. peace support operations). Atsako i krizes operacijos - tai NATO vadovaujamos ne 5 straipsnio operacijos, kurios

${ }^{41} 2008 \mathrm{~m}$. rugsèjo mèn. duomenys. 
apima paramą civilinei valdžiai, humanitarines operacijas, sankcijų igyvendinimą ir taikos palaikymo operacijas. Taikos palaikymo operacijos - tai NATO vadovaujamos operacijos, kurios apima konfliktu prevenciją, taikos kūrimą, taikos palaikymo operacijas, taikos įtvirtinimą ir taikos atstatymo operacijas ${ }^{42}$. NATO „kalba“ abiejų tipų operacijos vadinamos krizių valdymo operacijomis, kuriose gali būti naudojamos karinès ir nekarinès priemonès. NATO misija Afganistane - Tarptautinès saugumo paramos pajègos (angl. International Security Assistance Force - ISAF) - yra vienas iš pavyzdžių kaip karinės ir civilinès užduotys yra sujungiamos vienoje operacijoje. NATO deklaruoja, kad Aljanso tikslas yra padèti Afganistano vyriausybei išplèsti ir vykdyti savo valdžią bei įtaką visoje šalyje, sukurti sąlygas šalies stabilizavimui ir rekonstrukcijai, tačiau tuo pačiu metu šalies atstatymas ir tolimesnis vystymas yra integrali ISAF misijos dalis, kuri daugiausia vykdoma per 26 provincijos atstatymo grupes, sudarytas iš karinio ir civilinio personalo; pastarojo užduotis vykdyti taikos atstatymo funkcijas. Šios funkcijos yra: mokyklų ir medicininių paslaugų atkūrimas (2001 m. 8\% gyventojams buvo pasiekiama pirminė sveikatos apsauga, 2007 m. šis skaičius padidejo iki 83 \%; 2001 m. tik 1,2 mln. vaikų kasdien lankè mokyklą, šiuo metu ją lanko jau $7 \mathrm{mln}$., įskaitant ir $2 \mathrm{mln}$. mergaičių; be to, 2006 m. apmokyta apie 45,000 mokytojuc), geriamojo vandens tiekimo atstatymas, kelių rekonstrukcija, teritorijų išvalymas nuo minu (jau sunaikinta 88,136 priešpèstinių ir 11,524 prieštankinių minų), buvusių kovotojų demobilizacija ir reintegracija (jau nuginkluota ir reintegruota apie 60,000 gyventoju, 35-40,000 pareigūnų tarnauja nacionalinės policijos pajėgose, 30,000 karių - nacionalinëje armijoje), pabėgèlių sugrąžinimas (4,8 mln. pabėgèliu jau grįžo, iš kurių 3,5 mln. su JT pagalba $)^{43}$. NATO misija Irake taip pat turètų būti apibūdinta kaip turinti taikos atstatymo operaciju pobūdi, nes pagrindinis tikslas yra mokyti Irako karinį personalą, remti šalies saugumo institucijų plètrą ir koordinuoti paramos pristatymą. Afganistane taikos atstatymas vykdomas pasitelkiant ir karini, ir civilinị personalą, Irake tik kariai atsakingi už misiją, tačiau abu šie atvejai turi būti laikomi taikos atstatymu, nes operacijų užduotys siejamos su šalių rekonstrukcija ir vystymu bei įtraukia klasikines taikos atstatymo operacijas.

\subsection{ESBO ir taikos atstatymo operacijos}

Taikos atstatymas taip pat yra ir regioninių organizaciju naudojamas būdas. Europos saugumo ir bendradarbiavimo organizacija yra didžiausia regioninė saugumo organizacija, turinti 56 narius Europoje, Centrinėje Azijoje

\footnotetext{
${ }^{42}$ LR Krašto apsaugos miniterija, „Tarptautinių operacijų apibrėžimai“, http://www.kam.lt/index.php/ 1t/144614/, 200810 11; Ulozevičiūtė Ž., "Lietuvos dalyvavimas tarptautinèse taikos operacijose: narystės NATO ir ES iššūkiai”, Lietuvos metiné strategine apžvalga 2004, p. 215-228.

${ }^{43}$ NATO in Afghanistan. Reconstruction and development. June 2007, http://www.nato.int/issues/afghanistan/ factsheets/reconst_develop.html, 20080828.
} 
ir Šiaurès Amerikoje. ESBO veikia trijose saugumo dimensijose: politinëje - karinejje, ekonomikos ir aplinkosaugos bei žmogaus teisiu. Jos veiklos sfera apima daugelį su saugumu susijusių klausimu, tokių kaip ginklų kontrolè, pasitikẻjimo ir saugumo kūrimo priemonès, žmogaus teisès, nacionalinių mažumų apsauga, demokratizacijos procesai, kova su terorizmu, veikla ekonominëje ir aplinkosauginëje srityse. Taigi galima teigti, kad ESBO naudoja ankstyvo perspejimo, konfliktu prevencijos, krizių valdymo ir taikos atstatymo mechanizmus.

Politinëje - karinëje srityje ESBO veikia ginklų kontrolès (padeda sustabdyti ginklų plitimą ir siūlo pagalbą juos naikinant), sienų apsaugos (veiksmai nuo konfliktu prevencijos iki valdymo po konflikto, instituciju gebejjimu ir paramos joms skatinimo), kovos su terorizmu, konfliktu prevencijos, karinès reformos (ESBO bendradarbiavimo saugumo srityje forumas suteikia pagrindą politiniam dialogui dèl kariniu reformu, o praktiniai veiksmai vykdomi konkrečiu misiju metu), policijos srityse. Ekonominëje ir aplinkosaugos srityje ESBO veikia kovoje su nelegalia prekyba, skatina ekonomines iniciatyvas (kovoja su pinigu plovimu ir teroristu finansavimu, skatina gero valdymo principu diegimą, padeda valdyti migracijos srautus). Žmogaus teisių srityje ESBO veikla apima kovą su nelegalia prekyba, demokratijos principu skatinimą, žmogaus teises, mažumų teises, žiniasklaidos laisvę, tolerancijos skatinimą, teisės viršenybės principo diegimą, lyčiu lygybę, švietimą, pagalbą rinkimų metu. Visos šios priemonès turi būti vadinamos taikos atstatymo operaciju mechanizmais. Tai taip pat parodo, kiek skirtingų užduočių gali atlikti tie, kurie dalyvauja taikos atstatymo operacijose: nuo policijos funkcijų iki kariuomenės reformu, nuo kovos su pinigu plovimu iki gero valdymo principu diegimo, nuo žmogaus teisiu skatinimo iki pagalbos rinkimuose. Pavyzdžiui, ESBO biuro Baku užduotis yra įvykdyti teisinès sistemos, susijusios su rinkimais, žiniasklaida, pilietine visuomene, reformą, taip pat apmokyti policininkus ir kalëjimų darbuotojus.

\section{Taikos atstatymas Bosnijoje ir Hercegovinoje}

Tarptautinės bendruomenės nesugebẻjimas užkirsti kelio ar sustabdyti karus buvusios Jugoslavijos teritorijoje gali būti aiškinamas įvairiai - bendros politikos Europos Sajungoje nebuvimas, vyriausybiu nenoras suteikti reikiamus resursus, politiku trumparegiškumas. Mary Kaldor knygoje New \& Old Wars. Organized Violence in a Global Era ${ }^{44}$ teigia, kad tarptautinè bendruomenė nesuprato, kodèl ir kaip yra kariaujama. Politine ir karine prasme karas buvo suprantamas kaip konfliktas tarp tradiciniu nacionalistiniu grupiu, ir toks aiškinimas buvo tiesa ir Europoje, ir JAV, teigia autorė, tačiau toks aiškinimas neleido suprasti, kad tai buvo konfliktas tarp naujos formos nacionalizmo ir civilizuotų vertybių. Tarptautinè bendruomenè pakliuvo į nacionalistų spąstus

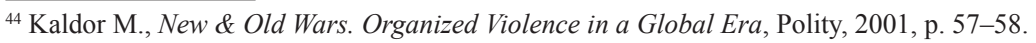


ir prisidejo prie nacionalistinių tikslų sklaidos. Netgi etniniai valymai buvo vertinami kaip šalutiniai karo padariniai.

Daugumoje buvusios Jugoslavijos respublikų $1991 \mathrm{~m}$. rinkimus laimëjo nacionalistinès partijos ir suformavo koalicines vyriausybes, nors partneriu tikslai dažnai ir skyrėsi: musulmonai nacionalistai norëjo centralizuotos nepriklausomos Bosnijos, serbų nacionalistai norëjo likti Belgrado dominuojamoje Jugoslavijoje, kroatai norëjo atkurti nepriklausomą Kroatijos valstybę ${ }^{45}$. Kroatijos ir Slovėnijos vyriausybės taip pat pasisakè už Jugoslavijos transformavimą i federaciją arba konfederaciją, serbai tuo tarpu pasisakẻ už labiau centralizuotą valstybès modelį. Tai lèmè, kad nacionalistinès pažiūros tapo dar radikalesnès ir $1991 \mathrm{~m}$. Kroatija ir Slovėnija paskelbė nepriklausomybę ${ }^{46}$. Po pirmuju rinkimu $1991 \mathrm{~m}$. Bosnijoje ir Hercegovinoje Nacionalinëje asamblëjoje dominavo trys etninès grupès, tačiau ji buvo silpna ir suformuota tik tam, kad komunistai būtu eliminuoti iš valdžios. Po Kroatijos ir Slovėnijos nepriklausomybės paskelbimo ir prasidejjusio karo Kroatijoje 1991 m., kada serbu karinès grupuotės, remiamos serbų dominuojamos Jugoslavijos kariuomenès, paskelbė Kroatijai priklausančių dalių atskyrimą tokiu būdu norėdami apginti serbų mažumų Kroatijoje teises, šios trys etninės grupės - bosniakai, serbai ir kroatai - atsidūré nedèkingoje padètyje. Labai greitai išsiskyrė nuomonès dẻl to, ar reikètu likti Jugoslavijos federacijoje (tokią poziciją rèmè serbai) ar siekti nepriklausomybès (šios nuomonès laikèsi bosniakai ir kroatai). Parlamento nariai serbai, daugiausia Serbu demokratų partijos nariai, boikotavo parlamento Sarajeve darbą ir $1991 \mathrm{~m}$. spalio 24 d. suformavo Bosnijos ir Hercegovinos serbų Asamblëją, o tai reiškẻ koalicijos darbo pabaigą. Asamblèja 1992 m. sausio 2 d. sukūrè Bosnijos ir Hercegovinos Serbijos respubliką, kuri rugpjūtį tapo Bosnijos serbų respublika (Republika Srpska). $1991 \mathrm{~m}$. referendumą dèl Bosnijos ir Hercegovinos nepriklausomybės dauguma serbų boikotavo. Referendume dalyvavo $63,7 \%$ gyventoju, iš kurių $99,4 \%$ pasisakẻ $u \check{z}$. Bosnija ir Hercegovina nepriklausomybę paskelbè nedalyvaujant asamblëjos nariams serbams. Netrukus po to seke įtampos ir pavieniu karinių incidentų eskalavimo periodas, o karas prasidejo balandžio 6 d. Sarajeve.

Po Bosnijos ir Hercegovinos nepriklausomybės paskelbimo, serbai atakavo ivvairias naujos valstybės teritorijos vietas. Naujoji administracija nesugebejo kontroliuoti teritorijos ir serbai greitai perėmè daugiau nei pusės valstybės teritorijos kontrolę ${ }^{47}$. Serbai norëjo visos teritorijos, kurioje daugumą sudarè serbai, t. y. rytinès ir vakarinès Bosnijos. Slobodano Miloševičiaus tikslas buvo atkurti Didžiają Serbiją ir šioje musulmonų teritorijoje ${ }^{48}$. Kroatai, siekdami apsaugoti daugiausia kroatų apgyvendintas Bosnijos ir Hercegovinos vietoves, paskelbė sukuriantys Herceg - Bosnijos Kroatijos Respubliką (kroatiškai - Hrvatska Republika Herceg-Bosna).

${ }^{45}$ Timeline: Bosnia-Hercegovina, http://news.bbc.co.uk/2/hi/europe/country_profiles/1066981.stm, 2008 0902 .

${ }^{46}$ Merlingen, (nuoroda 31) p. 53.

${ }^{47}$ Timeline: Bosnia-Hercegovina, (nuoroda 45).

${ }^{48}$ Kaplan L. S., NATO Divided, NATO United. The Evolution of an Alliance, Praeger, 2004, p. 116. 
Nuo krizės pradžios serbai atakavo civilius gyventojus ne serbus Rytų Bosnijoje. Tuomet, kai miestai ir kaimai jau būdavo jų rankose, serbų pajègos kariuomenė, sukarintos grupuotès ir netgi paprasti serbai - taikė vieną schemą: bosniakų namai buvo apieškomi ir sudeginami, civiliai bosniakai apsupami arba sulaikomi, o kartais ir sumušami ar net nužudomi. Karo pabaigoje buvo suskaičiuota apie 2,2 mln. pabėgèlių. Moterys ir vyrai buvo atskiriami, dauguma pastarujų buvo laikomi stovyklose. Moterys buvo laikomos pabėgèliu centruose, kuriuose jos būdavo išnaudojamos ir netgi dažnai prievartaujamos. Labiausiai žinomos yra 1995 m. įvykusios masinès žudynès Srebrenicoje, kurias Tarptautinis baudžiamasis tribunolas buvusiajai Jugoslavijai (TBTBJ) pripažino genocidu.

Tarptautinis Bosnijos ir Hercegovinos pripažinimas padidino diplomatinį spaudimą Jugoslavijos liaudies armijai (JLA) pasitraukti iš šalies teritorijos. Nors tai oficialiai ir buvo padaryta, JLA nariai Bosnijos serbai tiesiog pakeitė skiriamuosius ženklus, suformavo Bosnijos serbų respublikos armiją ir tęsẻ kovas. Apginkluoti ir aprūpinti iš JLA aprūpinimo dalinių Bosnijoje, remiami savanorių ir įvairių sukarintų grupių iš Serbijos, gaudami didelę humanitarinę, logistinę ir finansinę paramą iš Jugoslavijos Federacijos Respublikos, Bosnijos serbų respublikos kovotojai per 1992 metus sugebejjo perimti didesnès šalies teritorijos kontrolę. Tuo metu į konflikto sprendimą įsitraukė Jungtinės Tautos - $1991 \mathrm{~m}$. rugsèjo $25 \mathrm{~d}$. Saugumo Taryba vieningai prièmė rezoliuciją nr. 713, kuria išreikštas susirūpinimas situacija ir visos valstybės buvo paragintos igyvendinti „,visuotinị ir visapusišką visų rūšių ginklų ir karinės ekipuotės tiekimo Jugoslavijai embargą" ${ }^{49}$. Po mènesio generalinis sekretorius paskyrè savo asmenini pasiuntinį Jugoslavijai, kuris palaikẻ ryšius su Europos Bendrijoms pirmininkaujančia šalimi, Europos saugumo ir bendradarbiavimo konferencijos pirmininku, su Lordu Carringtonu - Europos Bendriju konferencijos Jugoslavijai pirmininku, ir su kitomis suinteresuotomis pusemis. Labai greitai JT apsisprende pradèti taikos palaikymo operaciją. 1992 m. vasarị Saugumo Taryba prièmė rezoliuciją nr. 743, kuria buvo pradèta UNPROFOR misija. Jos tikslas buvo sukurti taikią ir saugią aplinką, kad vèliau būtu galima derètis dèl visapusiško Jugoslavijos krizės sureguliavimo Europos Bendrijų konferencijos Jugoslavijai ${ }^{50}$. Pirminiame etape UNPROFOR taikdariai dislokuoti Kroatijoje ${ }^{51}$. 1992 m. liepą, kai konfliktas tapo intensyvesnis ir išsiplètė į Bosniją ir Herce-

\footnotetext{
${ }^{49}$ United Nations Security Council, Resolution 713, http://daccessdds.un.org/doc/RESOLUTION/GEN/ NR0/596/49/IMG/NR059649.pdf?OpenElement, 20080903.

${ }^{50}$ United Nations Protection Force, http://www.un.org/Depts/dpko/dpko/co_mission/unprof_b.htm, 2008 0903.

${ }^{51}$ UNPROFOR had a mandate to ensure that the three „United Nations Protected Areas“ (UNPAs) in Croatia were demilitarized. In the course of 1992, UNPROFOR's mandate was enlarged to include monitoring functions in certain other areas of Croatia (called „pink zones“); to enable the Force to control the entry of civilians into the UNPAs and to perform immigration and customs functions at the UNPA borders at international frontiers; and to include monitoring of the demilitarization of the Prevlaka Peninsula and to ensure control of the Peruca dam, situated in one of the "pink zones". In December 1992, UNPROFOR was also deployed in the former Yugoslav Republic of Macedonia, to monitor and report any developments in its border areas.
} 
goviną, UNPROFOR mandatas ir pajėgu skaičius padidinti tam, kad būtų užtikrintas Sarajevo oro uosto saugumas ir funkcionavimas bei humanitarinès pagalbos pristatymas. 1992 m. rugsëjo mèn. dar kartą praplèstas UNPROFOR mandatas - remti JT vyriausiojo pabėgèliu komisaro humanitarinès pagalbos teikimą visoje Bosnijos ir Hercegovinos teritorijoje bei saugoti neteisètai sulaikytus, tačiau vèliau paleistus civilius asmenis, jei to prašo Tarptautinis raudonojo kryžiaus komitetas. Be to, misijos pajėgos vykdè neskraidymo zonu monitoringą, uždraudžiant visus karinius skrydžius Bosnijos ir Hercegovinos oro erdvejje ir užtikrino JT Saugumo Tarybos nustatytų saugumo zonų apie penkis miestus ir Sarajevą funkcionavimą. UNPROFOR galëjo panaudoti jègą savigynai atsakant i saugumo zonų atakas ir koordinuoti su NATO oro pajėgu panaudojimą vykdant tokius atsakomuosius veiksmus. Tokie patys reikalavimai taikdariams buvo pradèti taikyti ir Kroatijos teritorijoje. Tačiau vis dèlto JT trūko pajègumų ir jos buvo nepasiruošusios $1992 \mathrm{~m}$. igyvendinti rezoliuciju nuostatas. ES bandymai apginti civilius, naudojantis UNPROFOR mandatu, nebuvo sèkmingi ir 1993 m. JT paprašè NATO parengti detalu planą, kuriuo būtų užtikrintas neskraidymo zonų saugumas ${ }^{52} .1995$ m. kovo 31 d. Saugumo Taryba prièmé sprendimą restruktūrizuoti UNPROFOR ir misiją pakeitè trimis atskiromis, tačiau tarpusavyje susijusiomis taikos palaikymo operacijomis.

1993 metais, kai ginkluotas konfliktas išplito ir tarp bosniakų dominuojamos vyriausybės Sarajeve bei Kroatijos Herceg - Bosnijos Respublikos, apie 70 procentų teritorijos kontroliavo Bosnijos serbų Respublika.

1994 m. kovą pasirašytas Vašingtono susitarimas tarp respublikos vyriausybès ir Herceg - Bosnijos lyderiu lèmè, kad buvo sukurta viena bosniaku - kroatų Bosnijos ir Hercegovinos Federacija, kuri apėmė Kroatijos Herceg - Bosnijos respublikos teritorija, ir kurioje veikè Bosnijos ir Hercegovinos Respublikos armija (bosniakų kariuomenè). Nepaisant daugybès JT ir ES pastangu, konfliktas truko daugiau nei trejus metus.

NATO bombardavimo kampanija prasidèjo 1995 m. rugpjūti prieš Bosnijos serbų Respubliką, po žudynių Srebrenicoje. Kartu su Kroatijos ir bosniaku ginkluotuju pajėgu veiksmais tai lemè, kad buvo palaužtos serbu pajègos ir dalinį kolapsą patyrè Bosnijos serbų Respublika.

1995 m. gruodį Deitone (Ohajas, JAV) Bosnijos ir Hercegovinos, Kroatijos ir Serbijos prezidentams Alijai Izetbegovičiui, Franjo Tuđmanui ir Slobodanui Miloševičiui pasirašius taikos susitarimą, buvo baigti kariniai veiksmai ir nustatyta iki šiol funkcionuojanti valstybès struktūra. Šiuo metu nustatytas karo aukų skaičius yra 97207, apie 110000 civilių ir karių žuvo, 1,8 mln. buvo priversti bejgti iš savo namų.

Šiandien Bosnija ir Hercegovina yra valstybė Balkanų pusiasalyje, užimanti 51,129 kvadratinių kilometru teritoriją ir turinti maždaug $4 \mathrm{mln}$. gyventoju $u^{53}$. Šalyje gyvena trys etninès grupès - bosniakai, serbai ir kroatai. Salis yra politiškai decentralizuota ir sudaryta iš dviejų subjektų: Bosnijos ir

\footnotetext{
${ }^{52}$ Kaplan, (nuoroda 48) p. 116-121.

${ }^{53}$ Timeline: Bosnia-Hercegovina, (nuoroda 45).
} 
Hercegovinos Federacijos (daugiausia apgyvendinta bosniakų ir kroatų), ir Bosnijos serbų Respublikos (daugiausia gyvena serbai), su Brčko sritimi kaip de facto trečiuoju subjektu.

Pagal Deitono susitarimą, taikos ígyvendinimo procesą prižiūri vyriausiasis igaliotinis Bosnijoje ir Hercegovinoje, kurị renka daugiau nei 50 šalių donorių sudaroma Taikos igyvendinimo taryba. Igaliotinis turi daug įstatymų leidžiamosios ir igyvendinančios galių, įskaitant ir renkamų bei skiriamų pareigūnu pašalinimą. Neseniai dalis subjektų jurisdikcijos buvo perduota valstybei ir buvo įkurtos naujos institucijos, tokios kaip, pavyzdžiui, gynybos ministerija, teismai, netiesioginių mokesčių tarnyba. Nuo 2002 m. kovo mèn. igaliotinis taip pat eina ir ES specialiojo atstovo pareigas. Šiuo metu pareigas užima Miroslav Lajcak iš Slovakijos, kuris prieš tai buvo ambasadorius Jugoslavijos Federacinei Respublikai (vèliau Serbijai ir Juodkalnijai), Albanijos Respublikai ir buvusiai Jugoslavijos Respublikai Makedonijai, taip pat dirbo ES vyriausiojo igaliotinio BUSP asmeniniu atstovu Juodkalnijai.

Deitono sutartimi nustatyta Bosnijos ir Hercegovinos politinè struktūra. Pagrindinès institucijos yra Prezidentas ir Ministrų Taryba. Prezidento instituciją sudaro trys nariai (bosniakas, serbas ir kroatas), piliečių renkami tiesioginiuose rinkimuose (federacija renka bosniaką ir kroatą, Bosnijos serbų Respublika - serbą). Kiekvienas iš narių pirmininkauja institucijai po aštuonis mėnesius, iš viso kadencija trunka ketverius metus. Ministrų tarybos pirmininką renka prezidentas, o tvirtina Atstovų rūmai. Ministrų tarybos pirmininkas vèliau tvirtina ministru tarybos sudètį. Po 2007 m. ìvykusiu rinkimų Bosnijos serbas Nikola Spiric suformavo koalicinę vyriausybę, tačiau tų pačių metų lapkriti atsistatydino taip protestuodamas prieš vyriausiojo igaliotinio ir ES specialiojo atstovo Lajcak bandymus pradèti ES remiamas reformas šalyje. Atsistatydinimo kalboje jis teigè, kad Bosnija yra per ilgai valdoma tarptautinès bendruomenès. Tačiau jis į postą grižo dar tais pačiais metais, pažadėdamas įvykdyti tas reformas, kurios Bosniją priartins prie narystès NATO ir ES ${ }^{54}$.

Parlamentinė Asamblëja yra legislatyvinė valdžia Bosnijoje ir Hercegovinoje. Ji sudaryta iš dviejų rūmų: Tautos rūmų ir Atstovų rūmų. Tautos rūmai turi 15 delegatu, du trečdaliai iš juc yra federacijos atstovai (5 kroatai ir 5 bosniakai), vienas trečdalis - Bosnijos serbų Respublikos (5 serbai). Atstovu rūmai sudaryti iš 42 narių, kuriuose etninès grupès atstovaujamos tokiomis pačiomis proporcijomis kaip ir Tautos rūmuose.

Vis dèlto aukščiausia politinè valdžia valstybejje yra vyriausiasis igaliotinis Bosnijai ir Hercegovinai, kuris gali tiek ignoruoti Parlamentinès Asamblëjos sprendimus, tiek ir nušalinti išrinktus pareigūnus. Bosnijos ir Hercegovinos tarptautinė „priežiūra“ turètų baigtis, kai šalis taps demokratinė ir politiškai stabili bei galès funkcionuoti pati, be kitų pagalbos.

\footnotetext{
${ }^{54}$ Country profile: Bosnia-Hercegovina, http://news.bbc.co.uk/2/hi/europe/country_profiles/1066886.stm, 20080903.
} 
Po Deitono susitarimo savo misijas Bosnijoje ir Hercegovinoje pradejo JT, NATO, ESBO.

Pagal Deitono sutartị $1995 \mathrm{~m}$. gruodį NATO dislokavo savo vadovaujamą IFOR (angl. Implementation Force) misiją, susidedančią iš 60,000 kariu, vieneriems metams su užduotimi prižiūrèti sutarties karinių aspektų igyvendinimą. IFOR taip pat padejo ESBO $1996 \mathrm{~m}$. rugsèjį surengti ir prižiūrèti pirmus laisvus rinkimus Bosnijoje ir Hercegovinoje bei padejo Vyriausiojo igaliotinio biurui kartu su Bosnijos ir Hercegovinos valdžia suformuoti naujas institucijas po rinkimu ${ }^{55}$. Taigi IFOR ne tik prižiūrèjo, kaip pagal susitarimą išvedamos pajègos, bet ir padejo atlikti taikos atstatymo operacijų užduotis - organizavo rinkimus ir prisidèjo prie institucijų kūrimo.

1996 m. gruodį IFOR pakeitė SFOR misija su 32,000 kariu, kurie turèjo užtikrinti stabilumą, kad būtu galima konsoliduoti taiką. $2003 \mathrm{~m}$. karių skaičius sumažintas iki 12,000, tačiau operacijos tikslas nepakito. $2004 \mathrm{~m}$. SFOR misiją pakeitė savarankiška ES operacija - EUFOR. EUFOR turi Saugumo Tarybos mandatą pagal VII Chartijos skyrių, kuris buvo atnaujintas 2007 lapkričio 21 d. rezoliucija nr. 1785. Misijos pradžioje ES dislokavo 7,000 kariu , kad būtų toliau igyvendinamas Deitono susitarimas. 2006 m. gruodi ES Taryba rekonfigūravo EUFOR-Althea, ir šiuo metu dislokuota apie 2,500 kariu $^{56}$. Pagrindinis misijos tikslas yra skatinti saugią aplinką šalyje, užtikrinti Deitono sutarties igyvendinimą, teikti paramą vyriausiajam igaliotiniui ir vietinès valdžios institucijoms. Be to, EUFOR teikia paramą TBTBJ ir atitinkamoms institucijoms, îskaitant ir paiešką žmonių, įtariamu karo nusikaltimais. Misija taip pat prisideda prie gynybos sektoriaus reformu Bosnijoje ir Hercegovinoje ${ }^{57}$.

Kaip buvo minèta, $1995 \mathrm{~m}$. JT nusprendè pradèti atskirą misiją Bosnijoje ir Hercegovinoje. 1995 m. gruodžio 21 d. Saugumo Taryba prièmè rezoliuciją nr. 1035 ir pradejo JT misiją Bosnijoje ir Hercegovinoje - UNMIBH. Ji apėmé JT Tarptautines policijos specialiosios paskirties pajėgas ir JT civilių užduočių biurą. Operacijos tikslas buvo įtvirtinti teisès viršenybės principą šalyje padedant reformuoti ir restruktūrizuoti vietinę policiją, îvertinti esamos teisinės sistemos funkcionavimą bei prižiūrèti ir audituoti policijos ir kitų institucijų, užtikrinančių tvarką ir teisės normų veikimą, darbą. Kaip teigia Merlingen ir Ostrauskaitė, JT tuo metu buvo vienintelè organizacija, turejusi patirties policijoje ${ }^{58}$. Vertindami misijos septyneriu metu darbą, autoriai teigia, kad vis dèlto policijos pareigūnai taip ir liko iš dalies etniškai susiskirstę, nekvalifikuoti, su mažais atlyginimais ir kartais netgi korumpuoti, nors, jei lyginsime su 1995 metais, situacija pagerèjo.

\footnotetext{
${ }^{55}$ NATO Handbook, Public Diplomacy Division, 2006, p. 144-145.

${ }^{56}$ European Union Council Secretariat, EU Military Operation in Bosnia and Herzegovina (Operation EUFOR-Althea), Factsheet, February 2008, http://www.consilium.europa.eu/uedocs/ cmsUpload/080220Altheaupdate10.pdf, 20080904.

${ }^{57}$ Ten pat.

${ }^{58}$ Merlingen, (nuoroda 31) p. 57.
} 
Iki 2004 m., kai buvo pradèta misija EUFOR-Althea, ES kontribucija taikos atstatymo procese pagal Deitoną buvo limituota. Tik $2003 \mathrm{~m}$. liepą ES pradejo savo policijos misiją - Europos Sajungos policijos misiją Bosnijoje ir Hercegovinoje (EUPM) - ir taip perėmė JT tarptautiniu policijos specialiosios paskirties pajėgu funkcijas. Po $2003 \mathrm{~m}$. vykusio ES ir Balkanu susitikimo bei 2004 m. liepos Europos viršūnių tarybos Briuselyje, ES persvarstė misijos mandato ir pajègu dydžio klausimus. Šiuo metu misijos mandatas pratęstas iki 2009 m. gruodžio 31 d. Šiandien misijoje tarnauja 173 pareigūnai iš 33 šaliu (147 policijos pareigūnai 26 civiliai). Misijos tikslas yra „,vadovaujant ir koordinuojant ES specialiajam atstovui bei turint omenyje platesnę teisès viršenybės sampratą Bosnijoje ir Hercegovinoje bei visame regione $<\ldots>$ patariant, vykdant stebejjimą ir tikrinimus, sukurti Bosnijoje ir Hercegovinoje ilgalaikes, profesionalias ir multietnines policijos pajėgas, veikiančias pagal Europos ir tarptautinius geros praktikos pavyzdžius ${ }^{\prime \prime 59}$. Šio tikslo yra siekiama per tris pagrindinius veiklos blokus:

- Parama vietos policijai, kovojant su organizuotu nusikalstamumu: EUPM prisideda prie Valstybinès tyrimų ir apsaugos agentūros transformacijos, kad ši institucija turètų didesnes ịstatymų ịgyvendinimo galias, kovojant su organizuotu nusikalstamumu. EUPM taip pat veikia, kad būtų vystomos ir kitos valstybinès institucijos, pavyzdžiui, Saugumo ministerija ir Sienų apsaugos tarnyba. EUPM pareigūnai pataria ir padeda planuoti bei vykdyti tyrimus ir operacijas susijusiais su organizuoto nusikalstamumo problemų sprendimu. EUPM taip pat skiria ypatingą dėmesi policijos ir prokuroru bendradarbiavimui.

- Vietos policijos atskaitomybė: EUPM vykdo arba prižiūri policijos darbą nuo pradinių planavimo stadijų iki tol, kol klausimas nepasiekia teismo.

- Pagalba iggyvendinant policijos reformą: EUPM siūlo techninę pagalbą bei pataria, kaip turètų būti keičiami teisės aktai vykdant policijos reformą. Policijos reformos departamentas kuria projektus, pagal kuriuos vystomos jau esančios policijos struktūros bei didinami operaciniai pajègumai ir efektyvumas ${ }^{60}$.

Merlingen ir Ostrauskaite detaliau analizuoja EUPM atliktas reformas, šiame straipsnyje pateikiama tik keletas pavyzdžių tam, kad būtų išryškintas taikos atstatymo operaciju turinys. Organizuotas nusikalstamumas buvo minima kaip didžiausia grėsmė valstybei ir visuomenei dar Europos Vadovu Tarybos susitikimuose. Misijos programų vystymo komitetas parengė keletą projektu, kurie pagerino teisminio tyrimo gebejjimus policijoje, užtikrino, kad vietiniai policijos detektyvai išklausytų bazinius mokymus apie kriminalinius

\footnotetext{
${ }^{99}$ Council Joint Action 2005/824/CFSP of 24 November 2005 on the European Union Police Mission (EUPM) in Bosnia and Herzegovina (BiH), http://eur-lex.europa.eu/LexUriServ/LexUriServ.do?uri=OJ:L:2005:3 07:0055:0058:EN:PDF, 2080905.

${ }^{60}$ European Police Mission in Bosnia and Herzegovina, (nuoroda 56).
} 
tyrimus specifinėse srityse, prisidèjo prie kompiuterinės sistemos, kuri sujungè visus policijos departamentus ir tokiu būdu igalino dalintis su nusikaltimais susijusia informacija, įdiegimo ir t.t. ${ }^{61}$. Kitas pavyzdys yra $2004 \mathrm{~m}$. kovą misijos žiniasklaidos padalinio inicijuotas projektas „Krimolovci“ (,Nusikaltèliu gaudytojai“"). Tai anoniminė, nemokama ir visą parą veikianti telefono linija, kuria paskambinę žmonès gali pasidalinti informacija apie neatskleistus nusikaltimus. $2007 \mathrm{~m}$. projekto pagalba prokurorai pradejjo 61 bylą, kuriomis atsakomybèn bus patraukti 84 asmenys. Dauguma nusikaltimų buvo susiję su nelegaliu ginklu laikymu ir nešiojimu, narkotiku laikymu ir prekyba. Be to, remiantis 67 pranešimais buvo pradèti kiti tyrimai ${ }^{62}$. EUPM padèjo vykdyti ir kitas kampanijas: „Vaša policija" (,Jūsų policija“) skatina visuomenę pasidalinti turima informacija ir tokiu būdu skatina policijos ir visuomenès bendradarbiavimą, skatina pasitikejjimą policija. Projektu „Izaberi Život, Ne Drogu“ („Rinkis gyvenimą, ne narkotikus") platinama informacija apie narkotikų keliamą pavojų.

Didinant vietinès policijos atskaitomybę buvo sukurtos keletas programų - policijos švietimo ir mokymo programa, vidaus reikalu programa. Mokymo programos tikslas yra, pavyzdžiui, suteikti žinių vadybos srityje, mokyti policijos pareigūnus, kaip paruošti tyrimo ataskaitą arba mokoma kriminalinių procedūrų taisyklių. Vidaus reikalų programoje kuriami skaidrūs patariamieji mechanizmai vietinèje policijoje - nustatomi profesiniai standartai, kuriamas skundų iš visuomenès biuras, kuriamos taisyklès, reikalingos šiems institutams funkcionuoti ${ }^{63}$.

Šiandien EUPM pasiekimus galima būtų susumuoti taip: valstybinės tyrimų ir apsaugos agentūros transformavimas į veikiančią policijos institucija, turinčią gebejjimų kovojant su organizuotu nusikalstamumu; kitų valdžios instituciju, ypač Saugumo ministerijos ir Pasienio policijos, plètra; policijos priežiūros komisijos, kurios nariai yra EUPM ir vietinės valdžios atstovai; bendras progresas, vykdant policijos reformą - EUPM vykdo pagrindinę patariamąją rolę. Stefano Recchia straipsnyje „Beyond international trusteeship: EU peacebuilding in $\mathrm{BiH}^{\prime 64}$ teigia, kad po Deitono susitarimo šalis buvo labai silpna ir nefunkcionavo bei greičiausiai nebūtų išgyvenusi be tarptautinès pagalbos. Tačiau autorius teigia, kad situacija pasikeitè tik tuomet, kai 2003 m. ES pradejjo savo misiją. Tik tuomet šalies institucijos tapo veikiančios ir dabar Bosnija ir Hercegovina turi visas galimybes tapti multietnine demokratija. Kita vertus, Recchia pažymi, kad ES privalo padidinti misijos efektyvumą ir politinę koordinaciją bei remti reformas ir tuomet, kai ES specialiojo atstovo biuro veikla bus baigta. Autorius manè, kad tai turètų atsitikti iki 2007 m. pabaigos, tačiau biuras dar veikia.

Po Deitono susitarimo pasirašymo, ESBO Bosnijoje ir Hercegovinoje turejjo tris pagrindines užduotis - organizuoti ir prižiūrèti rinkimus bei sukurti

\footnotetext{
${ }^{61}$ Merlingen, (nuoroda 31) p. 65.

${ }^{62}$ Krimolovci, http://www.eupm.org/Details.aspx?ID=10\&TabID=8, 20080910.

${ }^{63}$ Merlingen, (nuoroda 31) p. 67.

${ }^{64}$ Recchia S., ,,Beyond international trusteeship: EU peacebuilding in Bosnia and Hercegovina“, Occasional Paper No 66, February 2007, http://www.iss.europa.eu/uploads/media/occ66.pdf, 20080911.
} 
nuolatinę Rinkimų komisiją, sukurti ir igyvendinti susitarimą pasitikëjimo atmosferai kurti, saugumo situacijai gerinti ir ginklų kontrolei užtikrinti bei paskirti Žmogaus teisių ombudsmeną, prižiūrèti situaciją žmogaus teisių srityje $^{65}$. Šiandien ESBO misija Bosnijoje ir Hercegovinoje dirba šiose pagrindinėse srityse: demokratizacija, švietimas, žmogaus teisés ir saugumas. Darbas šiose srityse vykdomas per įvairius projektus. Demokratizacijoje ESBO savo dèmesi yra sutelkusi ị gero valdymo principu diegimą, pilietinès visuomenès ir vietinès valdžios kūrimą. Pavyzdžiui, buvo sukurtas specialus projektas „Ugovor" („Supratimas“) stiprinti visuomenès ir vietinės valdžios ryšius. Gero valdymo principų diegimo srityje taip pat sukurta keletas projektu, pavyzdžiui, Parlamentinès Asamblejjos darbą norima sustiprinti Paramos parlamentui ir įstatymdavystès stiprinimo programomis, didinant institucinius pajègumus bei didinant visuomenès dalyvavimą, informuotumą apie teisèkūros procesus. Mokymų, tikslinių seminarų ir darbo grupių tikslas parengti taisykles kaip bendrauti su žiniasklaida, įtraukti visuomenę i parlamento darbą. Svietimo srityje ESBO identifikavo, kad reikia turèti mokyklas ir mokymosi priemones, kurioms įtakos nedarytų tendencinga politine įtaka. ESBO veikla apima įstatyminès bazès švietimo srityje vystymą ir stengiamasi mokslą padaryti pasiekiamu visiems. Pavyzdžiui, vienas iš svarbių Bendrojo susitarimo dẻl demobilizuotuc vaikų aspektų yra nustatyti kriterijus mokyklų pavadinimams ir simboliams, kad jie būtų nepolitiški. Pagal Deitono taikos susitarimą ESBO yra vis dar atsakinga už žmogaus teisiu problemas Bosnijoje ir Hercegovinoje. Organizacija dirba šiose srityse: ekonominès ir socialinès teisès, teisinė reforma, karo nusikaltimai, prekyba žmonėmis, nacionalinių mažumų teisės, nacionaliniu žmogaus institucijų stiprinimas. Pagrindinis darbas saugumo srityje yra ginklu kontrolè, institucijų kūrimas ir kariuomenės parlamentinės kontrolès principo sukūrimas (šiuo metu pagrindinè veikla yra remti visas saugumo sektoriaus ministerijas ir agentūras, ígyvendinant saugumo politikos plano gaires, kurios buvo patvirtintos Bosnijos ir Hercegovinos Prezidento 2006 m. vasarį).

\section{Vietoj išvadų}

Galima teigti, kad šiandien pagrindiniai stabilumo Bosnijoje ir Hercegovinoje garantai yra tarptautinès organizacijos - ES ir ESBO - bei politinè sistema, sukurta Deitono taikos sutartimi. Tačiau ES užsienio ir gynybos reikalų ministrai jau pradejo neoficialias diskusijas dèl misijos Bosnijoje ir Hercegovinoje užbaigimo, o tai gali destabilizuoti ne tik šią trapią valstybę, bet ir visą Balkanų regioną. Nerimą kelia vis dažniau pasirodančios Bosnijos serbų Respublikos deklaracijos apie nepriklausomybę arba prisijungimą prie Serbijos, ypač turint galvoje klausimus, susijusius su Kosovo padėtimi. ES valstybės narès turètuc

\footnotetext{
${ }^{65}$ The General Framework Agreement for Peace in Bosnia and Herzegovina, http://www.oscebih.org/ overview/gfap/eng/, 20080911.
} 
daugiau demesio skirti situacijai Bosnijoje ir Hercegovinoje. Ši problema taip pat buvo analizuojama per Europos Komisijos nario atsakingo už plètrą Ollijo Rehno vizitą 2008 spalio 10 d. Jis ir Lajcako pabrèžè, kad Bosnija ir Hercegovina turi išlikti vieninga valstybe, Bosnijos serbų Respublikos atsiskyrimo klausimas negali būti net diskutuojamas bei nebus toleruojamas ${ }^{66}$. Kita problema yra organizuotas nusikalstamumas, kuris vertinamas kaip pagrindinè kliūtis, ir kuri buvo minima dar pasirašant Deitono sutartị. Progresas šioje srityje yra akivaizdžiai per lètas. $2008 \mathrm{~m}$. spalio pradžioje susprogdintas prekybos centras Vitezo mieste, šis nusikaltimas tyrèju traktuojamas kaip teroristinis $\operatorname{aktas}^{67}$ bei yra akivaizdus signalas tarptautinei bendruomenei, kad Bosnijos ir Hercegovinos negalima palikti vienos spręsti šias problemas. Baigti taikos operacijas dar per anksti.

\footnotetext{
${ }^{66}$ Delegation of the European Commission to Bosnia and Herzegovina, Ollie Rehn, European Commissioner for Enlargement visited Bosnia and Herzegovina today, 2008 m. spalio 10 d., http://www.europa.ba/?akc ija=vijesti\&akcija2=pregled\&jezik=2\&ID=317, 20081013

${ }^{67}$ Pincominfo, Za podmetanje eksploziva u FIS Vitez osumnjičen Suvad Džidić, 2008 m. spalio 12 d., http:// www.pincom.info/bih/opsirnije.asp?ID=60025, 20081013.
} 